https://doi.org/10.31470/2706-7904-2021-16-264-268

\title{
ПОЛІСЕМІЯ ЯК ПСИХОЛІНГВІСТИЧНА ПЕРЕДУМОВА ВИНИКНЕННЯ ІНТЕРФЕРЕНЦІЇ У ПРОЦЕСІ ВИВЧЕННЯ АНГЛІЙСЬКОї МОВИ
}

\section{Polysemy as a Psycholinguistic Precondition for the Emergence of Interference in the Process of Learning English}

\begin{abstract}
Olena Semenova
Ph.D. in Philology, Associate Professor

Horlivka Institute for Foreign Languages

of State Higher Educational Institution 'Donbas State Pedagogical University (Ukraine)

o.semenova@forlan.org.ua

https://orcid.org/0000-0002-7703-2719

Nina Khrystych

Ph.D. in Pedagogy, Associate professor

Hryhorii Skovoroda University in Pereiaslav (Ukraine)

forkaf@ukr.net

https://orcid.org/0000-0002-6839-8946

Abstract

The article presents the results of the study of interference in the process of learning English. Interference is regarded as a psychologically phenomenon of mixing codes at the level of speech activity of separate bilingual or multilingual individuals, which can occur both in the subconscious and in the conscious levels. The author investigates polysemy as a precondition of interference. The author concludes that in the process of speech, the language unit functions, on the one hand, as a unit of vocabulary, and on the other - as a component of the general structure of memory based on associative components.
\end{abstract}

Key words: polysemy, interference, interlingual parallelism, bilingualism, English.

\section{Вступ \\ Introduction}

Міжмовна інтерференція - це відхилення від норм мовлення, а причинами іiі виникнення $є$ розбіжність обсягу значень, невідповідність лексичної сполучуваності та асоціативних зв’язків у рідній та іноземних мовах. 
Розуміння інтерференції різними мовознавцями коливається між значеннями «мовні контакти», «взаємовплив мов», «змішування мов», «схрещування мов», «іншомовний вплив».

Дослідження міжмовної інтерференції перебуває в центрі проблематики мовних контактів, оскільки саме через двомовних чи полімовних індивідів здійснюється та або інша форма впливу однієї мови на іншу. У період глобалізації міжмовна інтерференція набуває великого розмаху. Слід зауважити, що мова не йде про запозичення, як просте застосування іншомовних слів у мові-реципієнті, як наприклад, вживання англіцизмів в українській чи будь-якій іншій мові, а мова йде про мовний взаємовплив.

Мета роботи полягає у дослідження полісемії як передумови виникнення лексичної інтерференції у процесі вивчення англійської мови.

\section{Методи та методики дослідження Methods and Techniques of the Research}

Для розв’язання поставлених завдань використовувались наступні методи дослідження: критичний аналіз науково-педагогічної, психологічної та методичної літератури з проблеми дослідження; аналіз підручників, навчально-методичних комплексів з англійської мови; метод педагогічного аналізу застосовувався для виявлення інтерферентних явищ на мовних рівнях (фонетичному, лексичному та граматичному); спостереження за процесом формування фонетичної, лексичної та граматичної компетенції мовців у процесі оволодіння ними англійської мови.

\section{Результати}

Results

Інтерференція - це психологічно зумовлене явище змішування кодів на рівні мовленнєвої діяльності окремих дво- або багатомовних індивідів, що може відбуватись як у підсвідомому, так і в усвідомленому рівнях. Слід зазначити, що « ... явище мовної інтерференції виявляється у різних аспектах: лінгвістичному, психологічному, лінгводидактичному» (Христич, 2020). По своїй суті явище інтерференції має психічну природу і базується на міжмовному паралелізмі. На підсвідомому рівні у білінгва наявна певна поняттєва базова мова-шаблон, яка залежно від комунікативного коду набуває подібної фонетико-лексичної чи лексикограматичної реалізації, в якій семантично однотипні знаки різних мов розцінюються як прямі відповідники базової мови-шаблонна. 
Л. Чайка (Чайка, 2008: 296) виділяє щонайменше три аспекти, що демонструють причини виникнення явищ, які стимулюють розвиток міжмовного паралелізму: «порівняльно-історичний, ареальний та типологічний».

С. Скрильник, зазначає, що явище мовної інтерференції носить суперечливий характер. На думку С. Скрильника (Скрильник, 2011: 348), мовна інтерференція «є складовою мовного контакту, багатоскладовою системою взаємовпливу, взаємопроникнення та взаємодії мовних та мовленнєвих одиниць. Багатоплановість явища мовної інтерференції пояснюється ï всеохоплюючою дією на всі мовні рівні у процесі мовного контакту». Міжмовна інтерференція діє на всіх рівнях мови. С. Скрильник (Скрильник, 2011: 348), зауважує, що «універсалією є те, що жодний мовний контакт неможливий без інтерференції».

Слід зазначити, що інтенсивність мовної інтерференції залежить не тільки від мовних чинників, як наприклад «системні лакуни» (відсутність одиниці у мові), але i від інших екстралінгвітичних факторів (розвиток науки i техніки, суспільнокультурних, економічних явищ тощо). Етноспецифічність понять i уявлень зумовлюється не лише особливими, притаманними саме для цієї лінгвокультурної спільноти предметами, явищами, артефактами культури, а й особливостями їх мовного та мовленнєвого конструювання та вживання, психологічними особливостями сприйняття навколишнього середовища та особливими «картинами світу», що утворюються в межах певної національно-лінговокультурної спільноти. Саме така специфічність відбивається на підсвідомому рівні.

Звичайно, мовленнєва функція без мовленнєвого середовища не буде розвиватися. Правильність володіння мовою у дитячому віці переростає в стійкі лексико-граматичні навички у дорослому віці. Тому чистота мовного середовища у період опанування мовою має виняткове значення.

Інтерференція на психологічному рівні часто виникає внаслідок багатозначності слова (полісемії). Слід відмітити, що лексико-семантична інтерференція на рівні полісемії зумовлена нерозрізненням сем із загальною лексемою у складі одного слова. Це зумовлено, передусім, полісемією рідної мови. Візьмемо для прикладу лексичну одиницю «річ» і порівняємо іiі з відповідниками в англійській мові. Приклади наведено у Табл.1. 


\section{Таблиця 1}

Порівняння лексичної одиниці «річ» з ї відповідниками в англійській мові

\begin{tabular}{ll}
\hline \multicolumn{1}{c}{ Українська } & \multicolumn{1}{c}{ English } \\
\hline Духовна річ. & Spiritual thing. \\
\hline Таке існує. & That such a thing exists. \\
\hline Читання - це не для мене. & Reading is not my thing. \\
\hline І ще одне. & And another thing. \\
\hline Перше, що я подумав. & The first thing I thought. \\
\hline Як же так погано пішли справи? & How had thing gone so wrong? \\
\hline Це була найкрутіша річ, яку я коли-небудь бачив. & It was the cutest thing I have ever seen. \\
\hline Я не річ. & I'm not a thing. \\
\hline
\end{tabular}

Якщо порівняти речення 3 компонентом «річ» 3 англійськими та українськими еквівалентами, то зразу стає помітно певна лексична невідповідність. 3 таблиці видно, що англійський іменник широкої семантики «thing» має відповідники в українській мові - «річ», «предмет», «явище», «итука», «справа», «діло». Розвиток i функціонування лексичної одиниці «thing» веде до створення їх розгалуженої системи, що сприяє поступовому віддаленню первинного значення від наступних похідних у семантичному ланцюжку. Поступово слово втрачає етимологічні зв'язки, незважаючи на збереження проміжних ланок.

Індивідуальний лексикон кожного конкретного мовця формується на основі асоціювання лексикону з його рецепцією у межах лексико-семантичної системи мови i являє собою індивідуальну систему сприйняття інформації. Таким чином, індивідуальний лексикон мовця складає певну концептуальну основу номінації. Мовець вибирає ту або іншу одиницю номінації залежно від того, якою мірою іiі семантика задовольняє процес концептуалізації та комунікації.

\section{Висновки Conclusions}

Підсумовуючи вищевикладений матеріал, стає очевидним, що у комунікативному процесі мовна одиниця функціонує, з одного боку, як одиниця словникового складу, а 3 іншого, - як компонент загальної структури пам'яті, пов'язаної асоціативними зв'язками 3 іншими iï компонентами. Частина концептуальної мережі пам'яті мовця, що стоїть за словом, - лексикон актуалізується у процесі породження мовлення як особливий механізм, що забезпечує адекватний вибір слова. Ієрархія організації засобів номінації в систему в рамках лексикону створюється конкретною людиною через їі асоціації і, отже, варіюється від одного індивіда до іншого, що й веде до виникнення інтерференції на психолінгвістичному рівні. Детальне вивчення явища інтерференції $є$ перспективним, 
адже у сучасному суспільстві проблема мовних контактів $є$ багатоаспектною $\mathrm{i}$ проявляється у різних сферах життя людини.

\section{Література References}

Скрильник, С.В. (2011). Інтерферентність як перекладознавча категорія. Наукові записки «Studia in honorem». Серія: Філологічні науки (мовознавство), 116, 346-349.

Христич, Н.С. (2020). Способи запобігання лексичної інтерференції у процесі вивчення французької мови. Матеріали 2-ої Міжнародної науково-практичної конференції «Франкофонія в умовах глобалізації $і$ полікультурності світу». (м. Тернопіль, 19 березня) (с. 54-56). ТНПУ.

Чайка, Л.В. (2008). Загальнолінгвістичний потенціал проблем міжмовних паралелей. Лінгвістика: зб. наук. пр., 2(14), 293-301. 